\title{
Survival of cultured allografts in patients with burns assessed with probe specific for $Y$ chromosome
}

\author{
Avril M Burt, Christopher D Pallett, John P Sloane, Michael J O'Hare, Katharine F Schafler, \\ Pinhas Yardeni, Arieh Eldad, John A Clarke, Barry A Gusterson
}

Institute of Cancer

Research, Sutton, Surrey SM2 5NG

Avril M Burt, BSC, research assistant

Christopher D Pallett, FIMLS, senior technician Michael J O'Hare, PHD, senior scientist

Barry A Gusterson, MRCPATH, professor of histopathology

Royal Marsden Hospital, Sutton, Surrey SM2 5PT John P Sloane, FRCPATH, consultant histopathologist

Queen Mary's Hospital, London SW15 5PN Katharine F Schafler, MRCPATH, consultant histopathologist

John A Clarke, FRCS, consultant plastic surgeon

Department of Plastic and Maxillofacial Surgery, Shaare-Zedek Medical Centre, Jersusalem, Israel Pinhas Yardeni, MD, clinical research fellow

Arieh Eldad, MD, clinical research fellow

Correspondence to: Professor Gusterson.

BrMed f 1989;298:915-7

\section{Abstract}

The aim of the study was to determine the fate of cultured skin allografts ir itients with burns. In situ DNA hybridisation with $Y$ probe (pHY 2.1) was used to detect cells carrying the $Y$ chromosome (the probe being visualised by the alkaline phosphataseantialkaline phosphatase method) in biopsy specimens taken from cultured allografts derived from donors of the opposite sex to the recipients (20 patients with burns). Specimens were taken within a week, between one and three weeks, between four and six weeks, and more than six weeks after grafting. Only two of the 27 biopsy specimens contained cells that were the same sex as the donor; both were taken within a week after grafting. In the 25 other specimens the epithelial cells were the same sex as the recipient.

Cultured skin allografts showed no evidence of survival in patients with burns, which suggests that they are probably not suitable for long term management of burns but may be useful as short term biological dressings.

\section{Introduction}

The culture of keratinocytes and their use as grafts to cover burn wounds was first described by Green $e t$ al in 1979. ${ }^{1}$ Several centres have since carried out clinical trials of these techniques in patients with burns ${ }^{2-5}$ and leg ulcers. ${ }^{67}$ Autologous cultures, however, take a long time to grow and patients with burns need to receive a graft before such cultures are ready. Cultured human epidermal keratinocytes do not express HLA-DR antigens $s^{8}$ and the Langerhans cells tend to be lost during culturing, ${ }^{9}$ which suggests that cultured allografts may be used for skin grafting. We therefore used cultured keratinocytes from allogeneic donors as grafts for treating patients with burns immediately after they had been burnt. ${ }^{2}$ Clinically the appearance of the cultured allografts on the burn wounds was the same as that of equivalent cultured autologous grafts, and we did not observe any clinical or histological signs of rejection of the allograft. This in itself does not, however, provide direct evidence of the long term survival of cultured allografts or their contribution to a permanent epithelium. We report the study of cultured allografts in 22 patients with respect to clinical features, histology of the grafts, and the use of in situ DNA hybridisation with a probe specific for the $Y$ chromosome when the sex of the donor and recipient was mismatched. ${ }^{10}$

\section{Methods}

Table I gives the details of the 22 patients studied. Most were aged over 40, and, with one exception, patients under 16 were not included to avoid the further trauma of biopsy. Twenty patients had burns, one degloving, and one lichen planus. The area of the full thickness wound varied from $1 \%$ to $55 \%$ of the body surface area.

\section{CELL CULTURE AND GRAFTING}

Most cultured allografts were derived from samples from reduction mammaplasty, with some male skin from abdominal apronectomies. Samples were routinely tested for hepatitis B virus and HIV before use. The keratinocyte cultures used for grafting were produced essentially according to the method of Green et $a l,{ }^{1}$ except that when the initial cell numbers were sufficient to obtain inoculums of about $5 \times 10^{6}$ cells per flask $\left(75 \mathrm{~cm}^{2}\right)$ irradiated mouse feeder cells were not used. When confluent and stratified the cultures were backed with either soft paraffin gauze or Surfasoft (W and W Medsystem, United Kingdom) and released with $0 \cdot 2 \%(\mathrm{w} / \mathrm{v})$ pronase (Sigma). They were washed to remove components of the culture medium and enzyme and were transported to the burns unit moist and in a cool box. Most cultures were applied to the patients immediately after the excision of burnt tissue at operation.

During the two years of this study the grafting procedure was changed from placing the cultured epidermis directly on to the wound surface to placing it over a split skin graft expanded by using a Tanner van de Ruts mesher in the ratio of six to one (derived either from autografts or allografts of skin).

\section{HISTOLOGY}

Punch biopsy specimens $(2 \mathrm{~mm})$ were taken under local anaesthesia at intervals from areas of the wound that were clinically healing. When meshed split skin had also been grafted the region biopsied was selected so as to avoid the underlying mesh. Sections $(3 \mu \mathrm{m})$ were cut from tissue fixed in formal saline and embedded in paraffin wax and were mounted on slides that had been cleaned, washed, air dried, and coated with $0 \cdot 1 \%(\mathrm{w} / \mathrm{v})$ poly-L-lysine in $0 \cdot 1 \%(\mathrm{v} / \mathrm{v})$ aqueous Tween 20 . After dewaxing and rehydration sections for routine histology were stained with haematoxylin and eosin. Sections for in situ hybridisation were treated for 60 minutes at $37^{\circ} \mathrm{C}$ with proteinase $\mathrm{K}(200 \mu \mathrm{g} / \mathrm{ml}$; Sigma) in $20 \mathrm{mM}$ TRIS plus $2 \mathrm{mM}$ calcium chloride

TABLE I-Characteristics of 22 patients given cultured allografts

\begin{tabular}{lcc}
\hline & Male $(\mathrm{n}=18)$ & Female $(\mathrm{n}=4)$ \\
\hline Age (years): & & \\
Range & $1-73$ & $18-78$ \\
No aged $\leqslant 20$ & 2 & \\
No aged 21-40 & 7 & 1 \\
$\quad$ No aged $>40$ & 9 & 3 \\
Full thickness wound area (\%): & 21 & 13 \\
$\quad$ Mean & $5-55$ & $1-30$ \\
Range & & \\
\hline
\end{tabular}


adjusted to $\mathrm{pH} 7 \cdot 0$ with $1 \mathrm{M}$ hydrochloric acid. After enzyme treatment the sections were washed twice in distilled water for 10 minutes at $4^{\circ} \mathrm{C}$, dehydrated in graded ethanols, and air dried.

\section{IN SITU HYBRIDISATION WITH Y PROBE}

The probe used was pHY 2.1" from Amersham International. It was biotinylated by using a nick translation kit (Amersham International) according to the manufacturer's instructions. Carrier DNA was added to the biotinylated probe $(3 \mu \mathrm{g} / \mathrm{ml})$, and the probe was precipitated with ethanol, ${ }^{10}$ dried, and reconstituted at a concentration of $20 \mu \mathrm{g} / \mathrm{ml}$ in $10 \mathrm{mM}$ TRIS plus $1 \mathrm{mM}$ EDTA adjusted to $\mathrm{pH} 7 \cdot 4$ with $1 \mathrm{M}$ hydrochloric acid.

The hybridisation mixture consisted of biotinylated probe $2 \mu \mathrm{g} / \mathrm{ml}$ and $10 \%(\mathrm{w} / \mathrm{v})$ dextran sulphate in $50 \%$ $(\mathrm{v} / \mathrm{v})$ dimethylformamide in $\mathbf{0 . 3} \mathrm{M}$ sodium chloride plus $0.03 \mathrm{M}$ sodium citrate. The hybridisation mixture $(20 \mu \mathrm{l})$ was applied to each section and covered with a coverslip $(22 \times 22 \mathrm{~mm})$. The slides were incubated at $95^{\circ} \mathrm{C}$ for 10 minutes to denature the probe and tissue DNA; they were then transferred to a humid chamber and incubated overnight at $42^{\circ} \mathrm{C}$ to allow specific hybridisation. After removal of the coverslips slides were washed in $0.3 \mathrm{M}$ sodium chloride plus $0.03 \mathrm{M}$ sodium citrate solution for 20 minutes at room temperature; they were then washed twice in a one in 20 dilution of the sodium citrate solution for 15 and 30 minutes at $42^{\circ} \mathrm{C}$, followed by two washes for five minutes at room temperature in phosphate buffered saline ( $\mathrm{pH} 7 \cdot 2)$ with $0 \cdot 1 \%(\mathrm{w} / \mathrm{v})$ bovine serum albumin. The biotinylated probe was detected by using the alkaline phosphatase-antialkaline phosphatase method $^{12}$ with mouse monoclonal antibiotin ( 1 in 100 ; Dako, High Wycombe, Buckinghamshire) as the first antibody, followed by rabbit antimouse antiserum and the alkaline phosphatase-antialkaline phosphatase complex (Dako). Fast red substrate was used to visualise the enzyme. Sections were lightly counterstained with Mayer's haemalum and mounted in glycerine jelly. Sections of male and female skin were used as positive and negative controls.

\section{Results}

Twenty patients were given allografts from donors of the opposite sex. In 10 of the 22 patients meshed split skin allografts or autografts were used as substrate for the cultured allografts. These have been found to result in improved healing in conjunction with grafted cultured epithelium. Biopsy samples were taken

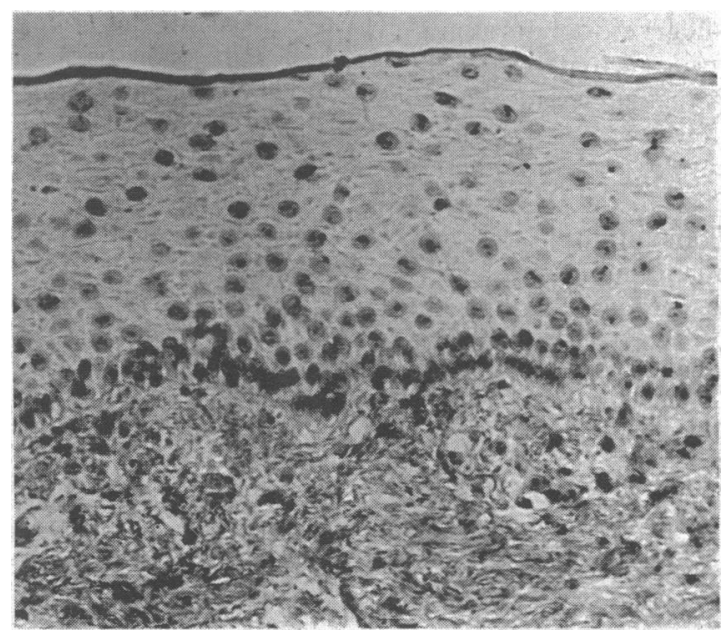

Biopsy specimen three weeks after grafting from male patient with burns given sex mismatched cultured allograft. Positive reaction with

$Y$ probe is seen as black dot in nucleus, showing that healing epidermis is not derived from female donor during routine changes of dressing at intervals between five days and nine months after grafting. Clinical success ("take") was generally assessed between three and four weeks when the area of healed wound was compared with the areas originally grafted. Individual patients showed a wide variation in clinical take, ranging from no visible healing to complete healing within the grafted area. In six of the 22 patients $(27 \%)$ no healing was observed, a result not dissimilar to our experience with routine split skin autografting in this type of patient. Three patients (14\%) given allografts showed less than $30 \%$ of the area healed, and in 13 patients (59\%) more than $30 \%$ of the wound area had healed and was covered with a visible epithelium. In comparison, patients with burns given conventional split skin autografts rarely show more than a $70 \%$ take. None of our patients with allografts showed any evidence of a classic rejection response macroscopically or histologically.

DNA hybridisation with the $\mathrm{Y}$ probe results in the deposition of red stain at a single point corresponding to the $\mathrm{Y}$ chromosome within the nucleus of each male cell. In the male epidermis nuclei within the stratum germinativum and stratum spinosum are strongly stained (figure). In most of the sex mismatched grafts in our study female cultures were grafted on to male patients, although in three cases the converse was attempted. In neither case, however, were cells found within the area of the graft biopsied corresponding to the graft phenotype. The only exceptions were two cases in which a biopsy was taken during the first week after sex mismatched cultures were grafted (table II). In all other cases examined (20 patients, 25 biopsy specimens) the epithelium in the grafted area was the same sex as the patient.

TABLE II-Y probe hybridisation in cultured allografts

\begin{tabular}{lcc}
\hline & $\begin{array}{c}\text { No of biopsy } \\
\text { specimens }\end{array}$ & $\begin{array}{c}\text { No of biopsy specimens in which } \\
\text { cells of donor sex identified }\end{array}$ \\
\hline $\begin{array}{l}\text { Time after graft (weeks): } \\
<1 \\
1-3\end{array}$ & 4 & 2 \\
$4-6$ & 13 & \\
$>6$ & 5 & \\
\hline Total & 5 & 2 \\
\hline
\end{tabular}

«In three patients sequential biopsy specimens were obtained, all of which gave negative results for sex mismatched graft epithelium.

\section{Discussion}

Our results show that despite the clinical appearance of cultured allografts there is no evidence for long term survival of grafted epithelium in patients with burns. None of our patients showed any evidence of classic rejection either macroscopically, in the form of erythema or blistering, or microscopically, with leukocyte invasion and epithelial vacuolation. These results do not exclude the possibility of the inclusion of small numbers of grafted cells into rehealing host epithelium, particularly when the more difficult to identify female cells are grafted on to male hosts, but they do exclude a long term survival of the whole allograft. Despite these results, however, improved healing seems to be seen clinically using both cultured autografts and cultured allografts. Similar observations have been recorded in patients with leg ulcers treated with allografts. ${ }^{679}$ The mechanism whereby the improvement is obtained with allografts remains obscure. The additional nursing care and bed rest associated with the treatment of ulcers might improve the rehealing of host epidermis, but this is probably not the explanation in patients with burns. Alternatively, the cultured allografts may, despite their short life, provide a biological dressing that actively promotes the rehealing of host skin, possibly by secreting growth 
promoting factors into the area of the wound. If this is the case then short term biological dressings incorporating suitable human cell types, free from known viral pathogens, on a substratum compatible with the wound may provide a valuable adjunct to conventional grafting procedures, with the added advantage that such material can survive cryopreservation and be reconstituted for use in large amounts and at short notice.

The Institute of Cancer Research is supported by funds from the Cancer Research Campaign and the Medical Research Council.

1 Green $\mathrm{H}$, Kehinde $\mathrm{O}$, Thomas J. Growth of cultured human epidermal cells into multiple epithelium suitable for grafting. Proc Natl Acad Sci USA 1979;76:5665-8.

2 Clarke JA, Burt AM, Eldad A. Cultured skin for burn injury. Lancet 1986;ii:809.

3 Eisinger M, Monden M, Raaf JH, Fortner JG. Wound coverage by a sheet of epidermal cells grown in vitro. Surgery 1980;88:287-93.

4 Gallico GG III, O'Connor NE, Compton CC, Kehinde O, Green $H$.
Permanent coverage of large burn wounds with autologous cultured human EnglF Med 1984:311:448-51.

5 Hefton JM, Madden MR, Finkelstein JL, Shires GT. Grafting of burn patients with allografts of cultured epidermal cells. Lancet 1983;ii:428-30.

6 Leigh IM, Purkis PE. Culture grafted leg ulcers. Clin Exp Dermatol 1986;11:650-2.

7 Leigh IM, Purkis PE, Navsaria HA, Phillips TJ. Treatment of chronic venous ulcers with sheets of cultured allogenic keratinocytes. $\mathrm{Br}$ I Dermatol 1987;117:591-7.

8 Morhenn VB, Benike CJ, Cox AJ, Charron DJ, Engleman EG. Cultured human epidermal cells do not synthesize HLA-DR. $\mathcal{f}$ Invest Dermatol 1982;78:32-7.

9 Thivolet J, Faure M, Demidem A, Mauduit G. Cultured human epidermal allografts are not rejected for a long period. Arch Dermatol Res 1986;278. $252-4$.

10 Burns J, Chan VTW, Jonasson JA, Fleming KA, Taylor S, McGee JO'D. Sensitive system for visualising biotinylated DNA probes hybridised in situ: rapid sex determination on intact cells. F Clin Pathol 1986;38:1085-92.

11 Cooke HJ, Schmidtke J, Gosden JR. Characterisation of a human Y chromosome repeated sequence and related sequences in higher primates. Chromosoma 1982;87:491-502.

12 Cordell JL, Falini B, Erber WN, et al. Immunoenzymatic labelling of monoclonal antibodies using immune complexes of alkaline phosphatase and monoclonal anti-alkaline phosphatase (APAAP complexes). $f$ Histochem Cytochem 1984;32:219-29.

(Accepted 30 fanuary 1989)

\title{
Survival of cultured allogeneic keratinocytes transplanted to deep dermal bed assessed with probe specific for $\mathbf{Y}$ chromosome
}

\author{
Anne Brain, Patricia Purkis, Philip Coates, Michael Hackett, Harshad Navsaria, Irene Leigh
}

North East Thames

Regional Plastic Unit, St

Andrew's Hospital,

Billericay, Essex

Anne Brain, FRCS, registrar in

plastic surgery

Michael Hackett, FRCS,

consultant plastic surgeon

\section{London Hospital, London}

E1 1BB

Patricia Purkis, chief

technician

Harshad Navsaria, MSC, technician

Irene Leigh, MRCP, senior

lecturer in dermatology

Department of

Histopathology, St

Bartholomew's Hospital,

London EC1A 7BE

Philip Coates, PHD, research

scientist

\section{Correspondence and} requests for reprints to

Ms Anne Brain, Department

of Dermatology,

The London Hospital,

London E1 1BB.

Br Med f 1989;298:917-9

\begin{abstract}
To determine the survival of cultured allogeneic keratinocytes transplanted to a deep dermal bed 24 tattoos that had been removed by deep shave excision in 19 patients were grafted with sheets of cultured allogeneic keratinocytes from donors of the opposite sex. Cells carrying the $\mathbf{Y}$ chromosome were identified in biopsy specimens taken from the graft site by in situ DNA hybridisation with a biotinylated Y probe (pHY 2.1) and visualised with a technique using immunoperoxidase. The cultured allograft sites were biopsied one, two, and three weeks after transplantation. No male cells were identified in any biopsy specimen from female patients who were given transplants of male cultured keratinocytes, and all biopsy specimens from male patients, who received female cultured keratinocytes, showed percentages of male cells within the normal range for male skin.
\end{abstract}

The beneficial effects of cultivated allogeneic keratinocytes result from effects on wound healing other than forming a successful graft that "takes."

\section{Introduction}

Organs transplanted across a histocompatibility barrier are usually rejected within 10-14 days unless the host's immune system is suppressed. Transplanted organs contain passenger leucocytes, which include the antigen presenting cells that present antigen to helper $\mathrm{T}$ cells and may initiate the rejection of a transplant by expressing class II histocompatibility molecules and secreting cytokines. Eliminating such cells from allografts may reduce the graft's immunogenicity and prolong its survival. Culturing endocrine tissues such as thyroid ${ }^{1}$ and pancreatic islet cells ${ }^{2}$ both eliminates antigen presenting cells and prolongs the survival of the cultured cells when they are transplanted as a cultured allograft.

In skin grafts the main antigen presenting cells are Langerhans cells, which form $5 \%$ of the total mixed epidermal cell population. Seven to 10 days after a single cell suspension of mixed epidermal cells is cultured in vitro the Langerhans cells are lost, ${ }^{3}$ as determined by the expression of HLA-DR antigens. ${ }^{4}$ The mixed epidermal cell lymphocyte reaction in lost in parallel, which seems to confirm the loss of the Langerhans cells. ${ }^{5}$ Other cells with the potential ability to express class II antigens, such as endothelial cells, which are particularly important in rejection reactions, ${ }^{6}$ are also lost during the culture of keratinocytes from mixed suspensions.

Sheets of cultured autologous keratinocytes have been used as skin grafts in patients with severe burns, leg ulcers, ${ }^{8}$ and congenital skin diseases such as epidermolysis bullosa. ${ }^{9}$ The delay of three to four weeks in producing expanded sheets of cells from a donor specimen, however, remains a practical problem, especially for patients with burns. Thus cultured allogeneic keratinocytes were used as grafts in patients with burns and clinically the allograft seemed to be successful (to "take"). ${ }^{10}$ This failure of rejection was attributed to the loss of the passenger leucocytesthat is, Langerhans cells. In previous studies of transplantation the survival of skin grafts was prolonged when skin that had been irradiated with ultraviolet light was used; such irradiation also reduces the numbers of Langerhans cells. ${ }^{11}$

Subsequent studies of the fate of cultured allogeneic keratinocytes have been controversial, with little proof that the allograft took rather than accelerated wound healing. To distinguish the two processes requires a biological technique giving unequivocal results-for example, HLA analysis, DNA fingerprinting, or detecting the sex of cells. In 1982 Cooke $e t$ al characterised a sequence that was repeated in tandem with 2000 copies on the Y chromosome. ${ }^{12}$ This constitutes a fifth of the DNA and is located on the tip of the long arm. A simple reproducible method to detect this multiple copy human gene has been established. ${ }^{13}$

To establish whether cultured allografts take biologically we used in situ hybridisation with a biotinylated probe to the $\mathrm{Y}$ chromosome to detect the sex of cells in skin biopsy specimens taken from deep clean surgical wounds that had been grafted with sheets of cultured allogeneic keratinocytes from unrelated donors of the opposite sex to the patients. 